\title{
PENGGUNAAN KATA "KIRIK" DALAM KOMUNIKASI SEHARI-HARI MASYARAKAT CIREBON (KAJIAN SOSIOLINGUISTIK)
}

\section{Juwintan dan Citra Dewi}

Sekolah Tinggi Ilmu Bahasa Asing (STIBA) Invada Cirebon, Indonesia

Email: juwintan@gmail.com dan citrastibainvada@gmail.com

\section{Abstract}

The purpose of this study was to find out the use of the word kirik in the sociolinguistic state. The method used is quantitative method. The data obtained through the instrument in the form of questionnaires, the data is processed and then the results are described using descriptive description. Respondents in this study numbered 40 people consisting of 22 men and 18 women. From the results of the analysis, it was found that most respondents (75\%) used the word "kirik" in daily communication. Used in joke sites as much as 70\%, situation praised as much as $24 \%$, angry situations as much as $60 \%$. Thus it can be concluded that the word kirik is a word used in non formal situations is a variation in language to add a familiar atmosphere.

Keywords: the word kirik; cirebon language; sociolinguistics

\begin{abstract}
Abstrak
Tujuannya penelitian ini adalah untuk mengetahui penggunaan kata kirik dalam tataran sosiolinguistik. Metode yang digunakan adalah metode kuantitatif. Data yang didapat melalui instrumen berupa kuesioner, data diolah kemudian hasilnya dijabarkan dengan menggunakan penjabaran deskriptif. Responden dalam penelitian ini berjumlah 40 orang yang terdiri dari 22 laki-laki dan 18 perempuan. Dari hasil analisis didapat bahwa sebagian besar responden (75\%) menggunakan kata "kirik" dalam komunikasi sehari-hari. Digunakan dalam situsi bercanda sebanyak $70 \%$, situasi memuji sebanyak 24\%, situasi marah sebanyak $60 \%$. Dengan demikian dapat disimpulkan bahwa kata kirik merupakan kata yang digunakan dalam situasi nonformal merupakan variasi dalam berbahasa guna menambahkan suasana akrab.
\end{abstract}

Kata kunci: kata kirik; bahasa cirebon; sosiolinguistik

Coresponden Author

Email: juwintan@gmail.com Artikel dengan akses terbuka dibawah lisensi 


\section{Pendahuluan}

Disetiap daerah memiliki jenis-jenis bahasa yang berbeda seperti basa Cirebon atau yang dikenal dengan bahasa jawa Cirebon merupakan Bahasa daerah yang digunakan masyarakat Cirebon dan sekitarnya (Setyawan, 2011). Sejalan dengan yang diungkapkan oleh Salana bahwa bahasa Cirebon merupakan salah satu etnis budaya Cirebon yang berkedudukan sebagai Bahasa daerah dan masih digunakan oleh masyarakat baik lisan maupun tulisan (Salana, 2002). Sama halnya dengan Bahasa Jawa standar, Juwintan menyatakan bahwa Bahasa Cirebon juga secara leksikal maupun morfologi dapat digolongkan ke dalam tuturan ragam netral, ngoko, krama dan krama inggil (Juwintan, 2016).

Dalam berkomunikasi, penggunaan tuturan tersebut juga masih sering digunakan di lingkungan masyarakat Cirebon. Dalam prakteknya, ragam krama dan krama inggil digunakan saat berbicara dengan orang yang berkedudukan tinggi seperti orang tua, atasan, orang dengan status sosial lebih tinggi (Siregar, 2020), sedangkan bahasa ngoko digunakan saat berbicara dengan teman sebaya atau orang yang lebih muda (Mardikantoro, 2012).

Berbeda dengan di atas, di kalangan penutur sebaya atau lebih muda cenderung menggunaan bahasa kasar, maka munculah fenomena bahasa yang secara leksilal memiliki arti kurang pantas apabila diucapkan namun saat ini hal tersebut menjadi suatu kewajaran (Suryadi, 2013). Bisa juga dikatakan bahwa penggunaannya sudah menjadi salah satu variasi bahasa yang digunakan oleh masyarakat Cirebon yaitu penggunaan kata "kirik". Menurut KBBI, kata kirik merupakan kata dari bahasa jawa untuk anak anjing. Biasanya digunakan sebagai kata penghalus untuk makian "asu" (anjing). Kata "kirik" seringkali terdengar pada hampir sebagian besar percakapan bahasa Cirebon.

Berikut beberapa contoh kalimat yang mengandung kata "kirik" dalam percakapan sehari-hari. Data dibawah diambil dari rekaman wawancara observasi awal penelitian ini.

1) "Kirik ira ana ana bae"

Wah, kamu ada-ada saja

2) "Kirik jare Manto kuh bli mengkonon"

Masa sih! Kata manto, bukan begitu.

3) "Kirik kuh!!"

$\underline{\text { Sialan! }}$

4) "Kirik, keren pisan dekore cah"

Wow! keren sekali dekorasinya

Melihat contoh kalimat diatas dapat dilihat habwa kata "kirik" dapat diaplikasikan dalam berbagai bentuk kalimat. Penggunaanya bervariasi, mulai remaja, orang tua bahkan anak-anak pun menggunakan kata ini. Dikarenakan penggunanya yang semakin meluas di berbagai rentang usia dan tingkatan sosial masyarakat, penulis tertarik untuk melakukan penelitian terkait penggunaan kata "kirik" dalam komunikasi sehari hari 
masyarakat Cirebon. Tujuan dari penelitian ini adalah untuk mengetahui penggunaan kata kirik pada komunikasi masyarakat Cirebon dari rentang usia, pendidikan dan jenis kelamin.

Pada penelitian ini peneliti menggunakan kajian sosiolinguistik, yakni kajian yang berhubungan dengan Bahasa yang digunakan dilingkungan masyarakat. Hal ini dinyatakan (Aslinda, 2007) bahwa sosiolinguistik merupakan bidang ilmu antardisiplin yang mempelajari bahasa dalam masyarakat. Penelitian tentang kata kirik belum pernah dilakukan sebelumnya, adapun penelitian serupa yaitu penggunaan kata anjing dalam bahasa sunda yang diteliti oleh (Yudistira, 2015).

\section{Metode Penelitian}

Penelitian ini merupakan penelitian kajian sosiolinguistik (Simatupang, Rohmadi, \& Saddhono, 2019). Sosiologi adalah ilmu yang mengkaji hubungan manusia di dalam kemasyarakatan sedangkan linguistik adalah ilmu yang mengkaji kaidah-kaidah bahasa. Jadi, sosiolinguistik adalah ilmu antardisiplin, pertemuan empiris dari dua disiplin ilmu yang berkaitan erat (Chaer, 2014). Dalam hal ini tatanan masyarakat yang juga termasuk didalamnya bahasa yang menjadi identitas komunikasi suatu lingkup sosial masyarakat yang terkait erat satu dengan lainnya. Kajian ini digunakan untuk menggambarkan keadaan penggunaan bahasa dalam masyarakat. Sesuai dengan tema penelitian ini yakni penggunaan kata "kirik" dalam komunikasi sehari-hari masyarakat Cirebon.

Pada penelitian ini, penulis menggunakan metode deskriptif kuantitatif (Sugiyono, 2011). Penelitian kuantitatif merupakan metode untuk mencari dan mengumpulkan data yang dapat diukur dengan persentase atau angka. Dalam penelitian ini data dikumpulkan melalui kuesioner dan disebarkan secara random kepada responden dengan berbagai rentang usia. Remaja usia 13-17 tahun, dewasa dini dengan rentang usia 18-40 tahun serta dewasa madya usia 40 sampai dengan 50 tahun.

Berikut adalah pertanyaan yang diajukan pada kuesioner:

Tabel 1

Kisi-kisi kuesioner

\begin{tabular}{cll}
\hline NO. & \multicolumn{1}{c}{ PERTANYAAN } & YA TIDAK \\
\hline Q1 & $\begin{array}{l}\text { Apakah anda menggunakan kata "Kirik" dalam percakapan } \\
\text { sehari-hari? }\end{array}$ & \\
\hline Q2 & Apakah kata "Kirik" digunakan hanya pada teman sebaya? & \\
\hline Q3 & $\begin{array}{l}\text { Apakah menurut anda kata "Kirik" merupakan bahasa } \\
\text { kasar? }\end{array}$ & $\begin{array}{l}\text { Bercanda } \\
\text { Marah } \\
\text { Q4 }\end{array}$ \\
& $\begin{array}{l}\text { Pada situasi apa anda menggunakan kata "Kirik"? } \\
\text { (Boleh jawab lebih dari 1) }\end{array}$ \\
\hline
\end{tabular}

Data yang telah diperoleh kemudian diolah menggunakan rumus prosentase untuk mengetahui tingkat prosentase penggunaan, kebiasaan, serta pada situasi apa kata kirik digunakan. Rumus prosentase yang digunakan sebagai berikut: 


\section{Gambar 1 \\ Rumus prosentase}

$$
\mathrm{P}=\mathrm{f} / \mathrm{N} \times 100
$$

(Sudjana, 2001)

Dimana:

P : prosentase

F : Frekuensi

$\mathrm{N} \quad$ : Jumlah responden

Kemudian data yang berupa prosentase tersebut disajikan dengan interpretasi menurut (Arikunto, 2010), untuk mengetahui penggunaan kata "kirik".

Tabel 2

Tabel Interpretasi

\begin{tabular}{cc}
\hline Interprestasi & Persentase \\
\hline Seluruh & $100 \%$ \\
\hline Hampir seluruh & $76-99 \%$ \\
\hline Sebagian besar & $51-75 \%$ \\
\hline Setengahnya & $50 \%$ \\
\hline Hampir setengahnya & $26-49 \%$ \\
\hline Sebagian kecil & $1-25 \%$ \\
\hline Tidak Satupun & $0 \%$ \\
\hline
\end{tabular}

\section{Hasil dan Pembahasan}

Dari 40 responden yang mengisi kuesioner dengan pertanyaan mengenai penggunaan kata "kirik" dalam komunikasi sehari hari. Didapatkan hasil yang dipaparkan sebagai berikut;

Tabel 3

Pertanyaan Q1

\begin{tabular}{cccc}
\hline NO. & PERTANYAAN & YA & TIDAK \\
\hline Q1 & $\begin{array}{l}\text { Apakah anda menggunakan kata "Kirik" } \\
\text { dalam percakapan sehari-hari? }\end{array}$ & $75 \%$ & $25 \%$ \\
\hline
\end{tabular}

Menurut hasil analisis data untuk Q1, bahwa sebagian besar responden (75\%) menggunakan kata "kirik" dalam percakapan sehari-hari. Sedangkan hanya sebagian kecil (25\%) yang tidak menggunakan kata "kirik" dalam percakapan sehari-hari. 
Tabel 4

Pertanyaan Q2

\begin{tabular}{cccc}
\hline NO. & \multicolumn{1}{c}{ PERTANYAAN } & YA & TIDAK \\
\hline Q2 & $\begin{array}{l}\text { Apakah kata “Kirik” digunakan hanya pada } \\
\text { teman sebaya? }\end{array}$ & $72,5 \%$ & $27,5 \%$ \\
\hline
\end{tabular}

Menurut hasil analisis data Q2, bahwa sebagian besar responden (72,5\% ) menggunakan kata "kirik" hanya pada teman sebaya. Hanya sebagian kecil $(27,5 \%)$ yang menggunakannya tidak hanya dengan teman sebaya.

Tabel 5

Pertanyaan Q3

\begin{tabular}{clccc}
\hline NO. & \multicolumn{2}{c}{ PERTANYAAN } & YA & TIDAK \\
\hline Q3 & $\begin{array}{l}\text { Apakah menurut anda kata } \\
\text { merupakan bahasa kasar? }\end{array}$ & "Kirik" & $92,5 \%$ & $7,5 \%$ \\
\hline
\end{tabular}

Menurut hasil analisis data untuk Q3, bahwa hampir seluruh (92,5\% ) responden menyatakan bahwa "kirik" merupakan kata kasar. Sedangkan hanya sebagian kecil $(7,5 \%)$ menyatakan tidak kasar.

Tabel 6

Pertanyaan Q4

\begin{tabular}{clll}
\hline NO. & \multicolumn{1}{c}{ PERTANYAAN } & \multicolumn{2}{c}{ JUMLAH } \\
\hline Q4 & Pada situasi apa anda menggunakan kata & Bercanda & $70 \%$ \\
& "Kirik"? & Marah & $60 \%$ \\
& (Boleh jawab lebih dari 1) & Memuji & $12,5 \%$ \\
\hline
\end{tabular}

Menurut hasil analisis data untuk Q4, bahwa sebagian besar responden (70\%) menggunakan kata "kirik" dalam situsi bercanda, sebagian kecil responden $(12,5 \%)$ menggunakannya dalam situasi memuji, sebagian besar $(60 \%)$ menggunakan dalam situasi marah.

Dari hasil analisis data mengenai penggunaan kata "kirik" dalam percakapan sehari-hari masyarakat cirebon. Didapatkan kesimpulan bahwa responden sebagian besar (75\%) menyatakan menggunakan kata "kirik" dalam percakapan sehari-hari. Makna kata "kirik"bersifat kasar disepakati hampir seluruh responden (92,5\%). Sedangkan hanya sebagian kecil $(7,5 \%)$ responden yang menyatakan tidak kasar.

Dapat disimpulakn bahwa kata "kirik" digunakan oleh sebagian besar responden (75\%). Sebagian besar responden (72,5\%) menggunakan kata "kirik" hanya pada teman sebaya. Hanya sebagian kecil $(27,5 \%)$ yang menggunakannya tidak hanya dengan teman sebaya. Dapat disampaikan juga kata "kirik" bisa digunakan terhadap mitra tutur selain orang yang sebaya. 
Sedangkan pada situsi penggunaannya, sebagian besar responden (70\%) menggunakan kata "kirik" dalam situsi bercanda, sebagian kecil responden $(12,5 \%)$ menggunakannya dalam situasi memuji, sebagian besar $(60 \%)$ menggunakan dalam situasi marah. Selanjutnya akan dipaparkan penggunaan kata "kirik" dilihat dari rentang usia, gender dan pendidikan responden.

Tabel 7

Rentang usia responden

\begin{tabular}{lcc}
\hline \multicolumn{1}{c}{ Usia } & Iya & Tidak \\
\hline $13-17$ tahun & 4 & 2 \\
\hline $18-40$ tahun & 25 & 8 \\
\hline $40-50$ tahun & 1 & - \\
\hline
\end{tabular}

Dari tabel diatas diketahui bahwa responden yang menggunakan kata "kirik" menurut usia dapat disampaikan sebagai berikut. Responden dengan rentang usia 13-17 tahun (remaja) sebanyak sebagian kecil (10\%), responden dengan rentang usia 18-40 tahun (dewasa dini) yaitu sebagian besar $(62,5 \%)$, dan sebagian kecil $(2.5 \%)$ responden dengan rentang usia 40-50 tahun (dewasa madya). Hal ini menunjukan bahwa penggunaan kata "Kirik" menyebar secara merata pada berbagai kelompok usia.

\section{Tabel 8}

\section{Jenis kelamin responden}

\begin{tabular}{lcc}
\hline \multicolumn{1}{c}{ Jenis Kelamin } & Iya & Tidak \\
\hline $\mathrm{L}$ & 18 & 4 \\
\hline $\mathrm{P}$ & 11 & 7 \\
\hline
\end{tabular}

Berdasarkan jenis kelamin, dari 40 responden yang diambil, dari 22 responden laki laki sebanyak 18 orang yakni $81 \%$ (hampir seluruhnya) menggunakan kata "kirik" dalam percakapan sehari-hari. Sedangkan dari 18 orang responden perempuan, 11 orang yakni $61 \%$ (sebagian besar) mengguanakan kata "kirik" dalam percakapan sehari-hari.

Tabel 9

\section{Latar belakang pendidikan responden}

\begin{tabular}{lcc}
\hline \multicolumn{1}{c}{ Pendidikan } & Iya & Tidak \\
\hline SD & 3 & - \\
\hline SMP & 6 & - \\
\hline SMA & 16 & 6 \\
\hline Sarjana & 4 & 5 \\
\hline
\end{tabular}

Dari latar belakang pendidikan responden. Mulai dari lulusan SD hingga Sarjana sebagian besar (75\%) menggunakan kata "kirik" dalam komunikasi sehari hari. Meskipun menurut data ada sebagian kecil $(27,5 \%)$ responden dengan latar pendidikan 
SMA dan Sarjana yang menyatakan tidak menggunakan kata "Kirik" dalam komunikasi sehari-hari.

\section{Kesimpulan}

Penggunaan kata "kirik" yang digunakan oleh masyarakat Cirebon termasuk kedalam variasi bahasa dan termasuk ranah kajian sosiolinguistik. Dalam prakteknya penggunaan kata "kirik" digunakan secara luas oleh masyarakat Cirebon. Berdasarkan hasil analisis data, pengguna bervariasi dari rentang usia remaja yang berusia 13-17 tahun hingga usia dewasa madya yang berusia 40-50 tahun. Penggunaannya juga tidak terbatas pada gender laki-laki saja namun juga pada perempuan. Hal ini menandakan bahwa kata "kirik" bersifat netral, tidak menjadi milik gender tertentu. Hal tersebut dapat dilihat dari data bahwa $11(61 \%)$ dari 18 orang responden wanita menjawab menggunakan kata "kirik" dalam pergaulan sehari-hari. Selain itu penggunaan kata "kirik" juga tidak terbatas pada tingkat pendidikan yang dimiliki penutur. Mulai dari responden berpendidikan SD sampai Sarjana menggunakan kata "kirik" sebagai bahasa pergaulan.

Hasil analisis yang telah dipaparkan diatas sejalan dengan apa yang disampaikan (Chaer, 2014) bahwa variasi bahasa terjadi bukan hanya karena diakibatkan oleh para penuturnya yang tidak homogen, tetapi juga dikarenakan interaksi sosial yang dilakukan sangat beragam. Setiap interaksi mengakibatkan terjadinya keberagaman bahasa, yang akan terus bertambah jika bahasa tersebut sering digunakan oleh penutur yang sangat banyak dan diwilayah yang luas.

Maka dapat disimpulkan bahwa kata "kirik" dalam bahasa Cirebon digunakan oleh masyarakatnya sebagai salah satu bentuk variasi bahasa yang digunakan secara luas. Bukan milik usia tertentu, gender tertentu atau status tertentu. Terlihat dari data bahwa kata "kirik" digunakan pada situsi yang bervariasi. Digunakan dalam situsi bercanda, situasi memuji dan situasi marah. Sejatinya kata "kirik" bersifat kasar. Namun pada perkembangannya kata "kirik" tidak dianggap kasar lagi oleh penuturnya namun lebih kepada kata yang digunakan untuk memberikan kesan akrab.

Pada penelitian selanjutnya dapat dilakukan penelitian dengan objek bahasa itu sendiri. Menelitii makna "kirik" dalam ranah kajian semantik maupun pragmatik. Data yang digunakan adalah rekaman ujaran yang mengandung kata "kirik". 


\section{BIBLIOGRAFI}

Arikunto, Suharsimi. (2010). Prosedur Penelitian Pendidikan Suatu Pendekatan Praktik. Jakarta: Rineka Cipta.

Aslinda, Leni Syafyahya. (2007). Pengantar Sosiolinguistik. Bandung: PT Refika Aditama.

Chaer, Abdul. (2014). Linguistik Umum Edisi Revis Cetakan Keempat. Jakarta. PT. Rineka Cipta.

Juwintan. (2016). Tingkat Tutur Bahasa Jawa Cirebon di Kalangan Generasi Muda.

Mardikantoro, Hari. (2012). Bentuk Pergeseran Bahasa Jawa Masyarakat Samin dalam Ranah Keluarga. LITERA, 11(2).

Salana. (2002). Wyakarana Tata Bahasa Cirebon. Bandung: Humaniora Utama Press.

Setyawan, Aan. (2011). Bahasa Daerah dalam Perspektif Kebudayaan dan Sosiolinguistik: Peran dan Pengaruhnya dalam Pergeseran dan Pemertahanan Bahasa.

Simatupang, Ruth Remilani, Rohmadi, Muhammad, \& Saddhono, Kundharu. (2019). Tuturan dalam Pembelajaran Bahasa Indonesia (Kajian Sosiolinguistik Alih Kode dan Campur Kode). Kajian Linguistik dan Sastra, 3(2), 119-130.

Siregar, Gustina. (2020). Sikap Masyarakat Penutur Bahasa Jawa Kromo Inggil di Desa Blitar Muka Kecamatan Sindang Kelingi Rejang Lebong terhadap Bahawa Jawa Kromo Inggil. JPT: Jurnal Pendidikan Tematik, 1(2), 42-50.

Sudjana. (2001). Metode Statistika. Bandung: CV.Tarsito.

Sugiyono, Prof. (2011). Metodologi Penelitian Kuantitatif Kualitatif dan R\&D. Alpabeta, Bandung.

Suryadi, M. (2013). Penggunaan Tingkat Tutur Bahasa Jawa Ngoko dan Krama pada Ranah Keluarga dan Masyarakat di Kota Semarang dan Kota Pekalongan. UNS (Sebelas Maret University).

Yudistira. (2015). Penggunaan Kata Anjing. 